Approches des domaines spécialisés en anglais de spécialité

\title{
Diachronic ESP: at the interface of linguistics and cultural studies
}

David Banks

\section{(2) OpenEdition \\ Journals}

Electronic version

URL: http://journals.openedition.org/asp/2738

DOI: $10.4000 /$ asp. 2738

ISSN: 2108-6354

\section{Publisher}

Groupe d'étude et de recherche en anglais de spécialité

\section{Printed version}

Date of publication: 15 March 2012

Number of pages: $55-70$

ISSN: 1246-8185

\section{Electronic reference}

David Banks, « Diachronic ESP: at the interface of linguistics and cultural studies », ASp [Online], 61 I

2012, Online since 07 October 2014, connection on 07 November 2020. URL : http://

journals.openedition.org/asp/2738; DOI : https://doi.org/10.4000/asp.2738

This text was automatically generated on 7 November 2020 .

Tous droits réservés 


\title{
Diachronic ESP: at the interface of linguistics and cultural studies
}

\author{
David Banks
}

\section{Introduction}

1 Over the last few years I have become interested in a subject which, for want of a better term, I call "diachronic ESP". ${ }^{1}$ Diachronic linguistics has existed since the early twentieth century, and, in a sense, existed before that in the form of philology. It has long been accepted that diachronic studies are of interest for language teaching, in that they can provide rational explanation for phenomena which otherwise appear to be haphazard exceptions. Thus, many of the problems inherent in English spelling, notoriously difficult for non-native learners, result from the fact that many phonological changes, notably the Great Vowel Shift, took place after spelling had been standardized. Thus the spelling represents a now obsolete pronunciation. Knowing that the spelling represents the way a word was pronounced at some point in the past, can help the learner come to terms with the apparent idiosyncrasies of contemporary spelling. What is true in general linguistics is, I believe, true also in ESP. Understanding the way specialized texts have developed can help us understand why they are the way they are today.

2 In my previous work (e.g., Banks 2009, 2010a, 2010b), I have usually analysed diachronic texts and attempted briefly afterwards to relate the analyses to the historical context. Here, I wish to devote most of the article to the historical context, and will then attempt briefly to show how some linguistic features fit into, and result from that context. Indeed, the texts cannot be fully understood without reference to the context of which they are a part.

3 My example is the academic research article, and my key date is 1665 . On 5 January 1665 , the first issue of the Journal des Sçavans appeared in Paris. This publication thus has the distinction of being the first academic periodical in history. It was followed two months later by the Philosophical Transactions, which first appeared in London on 6 
March 1665. Both of these periodicals still exist today, and have been considered major academic publications over the centuries of their existence.

\section{French historical context}

4 The seventeenth century began with Henri IV on the French throne. He reigned from 1589 to 1610 . He was succeeded by Louis XIII from 1610 to 1643, and when he died Louis XIV came to the throne. He was still a child at the time, and his accession was the beginning of the longest reign in French history, for he was on the throne until his death in 1715. Thus in 1643 opened one of the most stable periods ${ }^{2}$ in French history, with a highly centralized government dominated by the philosophy of the Divine Right of Kings. Louis XIV would of course later become known as the Sun King, the centre of the most powerful state in Europe, not only politically, but financially and culturally as well.

\section{English historical context}

Compare this with the situation on the other side of the Channel (Hill 1969). The year 1603 saw the accession of James I, who was already James VI of Scotland. The early years of his reign were marked by the Gunpowder Plot, when a group of conspirators, of whom the best known is Guy Fawkes, attempted unsuccessfully to blow up Parliament. This is still celebrated in England each year, on 5 November, Bonfire Night, with bonfires, fireworks and the burning of an effigy of Guy Fawkes. James I reigned until 1625 when he was succeeded by Charles I. Charles was involved in constant disputes with Parliament, mainly on two questions. The first was religion. Charles had Catholic sympathies, and there were numerous Catholics at court, while the Parliament was fiercely Protestant. The second question was that of finance. Charles had to raise money, but Parliament frequently disagreed with the legality of the means by which he chose to do so. These problems festered until they irrupted into civil war in 1642. The Civil War lasted until 1649, when Charles I was captured, tried, and executed by beheading (almost a century and a half before the French Revolution!).

6 From 1649 England was governed by Cromwell, who turned out to be no less repressive than the kings who had preceded him. It was a period dominated by Puritan principles, and these principles were imposed by force. Before he died in 1658, Cromwell appointed his son Richard as his successor. However, Richard did not have the same taste for power as his father, and the following year he resigned. This left the way open for the restoration of the monarchy, and in 1660 Charles II, the son of Charles I returned. However, there had been a distinct change in the balance of power. When his father came to the throne, the Divine Right of Kings was still the accepted philosophy of government, thus hampering Parliament's attempts to curb his activities. The terms of the Restoration invited Charles II back to a country that would be governed by "King, Lords, and Commons". So Charles II was no longer sole arbiter, but one of three elements in the Government. His reign was also marked by non-political catastrophes. In 1665 the Great Plague, or Black Death, struck London, killing 15\% of the population. In the following year, 1666, the Great Fire of London destroyed $80 \%$ of the city, including 13,000 houses, and 89 churches. 
7 Charles II lived till 1685, when he was succeeded by his brother, who became James II. Both of their reigns suffered from constant religious disputes with Parliament, similar to those of the reign of Charles I. Both Charles II and James II had wives who were Catholics, and there were numerous Catholics at court. Both kings had Catholic leanings, and James II in particular had openly Catholic sympathies. This came to a head in 1688 when Parliament invited William of Orange to come and take over the throne. James fled to exile in France. William was James' son-in-law, having married James' daughter Mary, and he was a grandson of Charles I. William and Mary were appointed joint monarchs, under the terms of the Glorious Revolution. It was those terms which established the first constitutional monarchy. Mary died in 1694, and William lived on, as William III, until 1702.

8 It is evident that the seventeenth century in England was a totally turbulent period. Moreover, it was a period of decreasing state control: from a situation dominated by the Divine Right of Kings at the beginning of the century, we pass to the establishment of a constitutional monarchy before the end. So the balance of power altered radically during the course of this century.

Hence, in my key year of 1665, France was in the middle of a period of total state control, with the Sun King, Louis XIV firmly in control of a highly centralized, powerful state. England, on the other hand, was basking in the new-found freedom of the Restoration, after the turbulent and repressive period of the Civil War and the Interregnum under the government of Cromwell.

\section{The academic situation}

10 The universities at this period were dominated by the study of the Ancients, notably, though not exclusively, Aristotle, Galen and Ptolemy. Academic study consisted in the explication of the Ancients' texts. The worldview of seventeenth century man was that the development of humanity was rather like that of the individual. Humanity's high point had been reached in its youthful period, that of ancient Greece and Rome. By the seventeenth century it was in its decline, and could not hope to equal the exploits of its youth (Jones 1982). Hence experiment was considered pointless. Since Aristotle and his ilk had already said everything that was relevant, all that could be done was explain their texts in terms of the seventeenth century situation; but discovering new facts, and even suggesting that Aristotle might have been wrong was not feasible. Aristotle and the other Ancients were the great authorities. Hence those who espoused experiment were, in general, outside the university system. Those interested in this new form of science tended to form groups where they met to discuss and to carry out experiments. The most important of these groups met in London and oxford, and crystallized in the creation of the Royal Society. The group which was to become the Royal Society was founded in 1660 , and officially became the Royal Society when it received its Royal Charter in 1662 (Lyons 1944). It is notable that few of the members of the Royal Society held university posts. Some of them had held such positions during the period when Cromwell was in power, but these were political appointments, replacing Royalists with Parliamentarians. And when the political tide changed at the Restoration, they were in their turn replaced by Royalists, and so lost their university posts. The obvious exception is of course Newton (Fara 2002; Gleik 2003; Panza 2003; 
White 1998), but it will be noted that he held a chair in mathematics, not as an experimental scientist.

The fact that the early members of the Royal Society were frequently of a Puritan persuasion is not anodyne. Scholastic philosophy, which lay at the basis of Catholic teaching, was Aristotelian in nature, so an empirical, experimental approach, which, of its nature, was opposed to Aristotelianism, at least as it was perceived in the late seventeenth century, was in line with Puritan thinking. Merton (1938) points out that Puritanism was particularly conducive to the development of empirical science. The influence of Calvinism led to the esteem of hard work as a principle of life and salvation, and hence to the development of the Protestant work ethic (Weber 1930). The object of human life was seen as the glorification of God, and this was attained by work which was socially useful. Whereas in the Catholic tradition the glorification of God had implied retreat from the world to monastic institutions, for the Puritans it meant greater implication in that world itself. For those who believed in the fullyfledged Calvinistic predestination, good works, that is, those that were useful and profitable, were an outward sign of having been chosen by God; for those who did not believe in predestination good works were a means of achieving a state of grace, and thus becoming one of God's elect. For Puritans with a scientific bent, the use of reason, the distinguishing feature of man, to study nature, God's creation, particularly if that study led to improvements in the human condition, was seen as a particularly effective way of glorifying God. Today, we live in a deeply secular environment, but this should not lead us to underestimate the prime importance of religion for these early empirical scientists.

\section{Retrospective distinctions}

Looking back from our twenty-first century viewpoint, it is easy to see clear distinctions and divisions. However, for the man on the ground at that time those distinctions may not have been clear at all. It must be remembered that the word "science" did not exist in our contemporary sense, simply having a meaning close to that of "knowledge". In the seventeenth century the term "natural philosophy" covered roughly what we refer to as "science and technology" (Banks 2004). Hence it was branch or subdivision of the general field of philosophy, rather than a totally distinct field of study. Moreover, the distinction between astrology and astronomy was still decidedly fuzzy, with the two shading into one another for many at that time. And alchemy was not totally distinct from physics and chemistry. It is notable that scientists as famous as Boyle and Newton continued practicing alchemy right up to the ends of their lives (Hunter 2010; Auffray 2000; Golinski 1989; White 1998). It was this world which saw the birth of the Royal Society of London, and of the Académie Royale des Sciences in Paris.

\section{The Royal Society}

13 As mentioned above, the group which was to become the Royal Society was founded in 1660 in the first flush of optimism and freedom that were the psychological results of the Restoration. A number of philosophical groups had been meeting in Oxford and London, the most important of these being the one which met at Gresham College. It 
was this group which crystallized into the Royal Society, though initially it had no official name. In 1661 they applied for a Royal Charter, which was granted in July 1662. However, it must be noted that although the Royal Society had the prestige of its Royal Charter, it was never financed by the Crown, except very occasionally for specific projects. Consequently, the Royal Society depended totally on the subscriptions of its members for its revenue. It is for this reason that the recruitment of aristocratic, and therefore rich, members was of vital importance for the survival of the society, even if they were not particularly scientific. Hence the Royal Society was totally independent, but that very independence involved financial problems (Lyons 1944; Gribbin 2005; Sorrenson 1996; Sprat 2003).

\section{The Académie Royale des Sciences}

The Académie Royale des Sciences was founded in Paris in 1666. It also was formed on the basis of already existing groups, notably the Petite Académie. This had been created, and was controlled, by the State in the person of Colbert, Louis XIV's first minister, or chancellor. The Académie Royale itself was founded as a royal institution; it was financed by the Crown, and its members were paid, thus making them the first scientific civil servants in history. Its premises were also supplied by the Crown. Colbert's objective in setting up the Académie Royale was the state control of new knowledge, as well as the glorification of the Sun King. It was intended that the spirit of the members should be collegial, and hence their publications, or memoires, were anonymous, being thought of as the productions of the Académie as a whole (Hahn 1971; Hirschfield 1981). Nor were they widely distributed; it was considered that they had been commissioned by the king and so were his property, and having been produced for the glory of the Sun King, that fact was of sufficient value in itself, and it was unnecessary to seek the added value of dissemination (Licoppe 1994, 1996; Biaglioni 1996).

\section{The Journal des Sçavans}

The Journal des Sçavans was founded in 1665 by Denis de Sallo, a year before the foundation of the Académie Royale des Sciences. He was a member of the Petite Académie, and founded the journal at the instigation of Colbert. This too was part of Colbert's control strategy. Although officially a private venture by Denis de Sallo, it does seem to have had state subsidies, frequently of a clandestine nature. Moreover, de Sallo was chosen by Colbert, and subsequent editors of the Journal des Sçavans continued to be appointed by Colbert, or his successors. The first issue appeared on 5 January 1665 , thus giving it the distinction of being the first academic periodical in history. In practice, it was basically a publication of book reviews, and it covered the whole area of new knowledge, including, for example, classics, law, and theology. ${ }^{3}$

\section{The Philosophical Transactions}

The Philosophical Transactions was founded as a private venture by Henry Oldenburg. He was one of the two secretaries of the Royal Society, but, unlike most members of the society, he was not a virtuoso, or gentleman scientist, with private financial means. He 
had to earn his living, and he saw the Philosophical Transactions as a way of augmenting his income. He had become the centre of a network of scientific correspondence, and his idea was to produce a newsletter based on the "intelligence" he received in his correspondence. It should be noted that although these letters were private, in the sense of having been sent from one individual to another, it was generally understood that it was the intention of the writers that they should be copied, sent on, read at meetings, and so on (Gotti 2006). Although the Philosophical Transactions was ordered by the Royal Society, and thus had its imprimatur, it remained the private property of Henry Oldenburg, who retained total editorial responsibility, but also total financial responsibility. Most of the content of the periodical was based on the letters Oldenburg received, and its scope was restricted to that of "natural philosophy", or science and technology in contemporary terms (Bluhm 1960; Hall 2002).

\section{Philosophical stance}

The Royal Society and the Philosophical Transactions were firmly in the tradition which had been set out by Francis Bacon, that is, a strictly empirical approach which starts from data, as the source of all knowledge (Robertson 1905; Henry 2002). This can be clearly seen in Sprat's History of the Royal Society, first published in 1667 (Sprat 2003). This is a "history" in the seventeenth century, and not the present-day sense, and is virtually a manifesto for the Royal Society. In it, Bacon is presented very much as a father figure, and maitre à penser of the Royal Society. This staunchly empirical approach can also be seen in such things as the first line of Newton's Opticks (Newton 1952), which reads: "My design in this Book is not to explain the Properties of Light by Hypotheses". Starting from hypotheses, and not from data, was precisely the approach espoused by Descartes and his followers. This was the approach which heavily influenced the Académie Royale and the Journal des Sçavans. Hence, for them, theory was all important, and what they put first. This does not, of course, mean that they never carried out experiments; on the contrary, the work of the Académie was devoted to experiment, but experiment for them was basically a way of testing theory. The theory itself was something that had been elaborated prior to the experimentation. The Baconian project was the accumulation of experimental facts and observations; the theory, it was thought, would emerge from the data. So the members of the Royal Society espoused an inductive approach, while members of the Académie preferred a deductive approach. This is, of course to some extent simplistic, in that, probably, pure deduction and induction do not exist. The inductive scientist has some idea of the theory he expects, or even wishes, to come out of his data. Nevertheless, the distinction does give a good idea of the different tendencies of scientific practice in England and in France at this period.

\section{Context and editorial decisions}

All of the above (and more, since this is just an outline) is the context which engenders the texts to be found in the Journal des Sçavans and the Philosophical Transactions. Colbert's objective, via de Sallo, was to create a journal with the idea of controlling new knowledge. But if one wants to control knowledge, to make sure that new, and even revolutionary, ideas, remain in the intellectual sphere, and do not spread to the 
political arena, then there is no point in controlling just a part of that new knowledge; all fields must be covered. This leads naturally to the editorial decision to cover the whole field of new knowledge. At the time there were two ways of disseminating new knowledge: one was by writing letters, the other by publishing books. Although, as pointed out above, these letters were more of a public nature than strictly private, it is evident that book publishing placed the content of the books more immediately in the public arena. It thus seems fairly natural that to deal with new knowledge one should treat new books, and the obvious way of doing this is to review them. Hence we have de Sallo's two editorial decisions: to treat the whole range of new knowledge, and to do this by reviewing books. Moreover, these two decisions derive directly from the centralized political situation in France. Oldenburg was in a quite different situation. His objective was the personal one of making money, and so he had to consider his potential readership which was basically composed of the members of the Royal Society and those with similar interests. And those interests were limited to the field of "natural philosophy", that is, science and technology. There would have been no point in him treating other areas for they would not have been of interest to his readership. Moreover, Oldenburg had a ready-made source of material in the scientific area available in the form of the correspondence he received. Hence, we have Oldenburg's two editorial decisions: to deal with scientific matters and to do so using the material furnished by his correspondence. Although perhaps less obvious than in the case de Sallo, I would claim that the new-found spirit of freedom generated by the Restoration was conducive to Oldenburg's enterprise.

\section{Linguistic features: themes}

19 I am arguing therefore that these editorial decisions taken by de Sallo and Oldenburg derive from the respective historical situations in France and England. I would contend further that the linguistic features to be found in their journals are a function of these editorial decisions. As examples of this I shall look briefly at three linguistic features: a semantic typology of topical themes, process types and modality. The terminology used is that of Systemic Functional Linguistics (Halliday 2004; Banks 2005), but I think that it is sufficiently transparent to be understood by readers not familiar with this particular approach. The figures given here are from previous studies (Banks 2009, 2010a, 2010b, forthcoming), and while based on admittedly small samples, give results which are totally consistent with, and explicable in terms of, the historical context.

Table 1 gives the semantic typology of topical themes. Theme is here defined as the speaker's starting point, topical theme being the obligatory element in the thematic material. Topical theme corresponds to one of the main grammatical constituents (subject, process, complement or circumstantial adjunct), and theme is realized in English by being placed in initial position in the clause. The semantic typology is based on that originally developed in Banks 2008.

Table 1. Semantic typology of topical themes

\begin{tabular}{|l|c|c|}
\hline & Journal des Sçavans & Philosophical Transactions \\
\hline Object of study & $8 \%$ & $77 \%$ \\
\hline
\end{tabular}




\begin{tabular}{|l|c|c|}
\hline Experiment & - & $4 \%$ \\
\hline Author & $12 \%$ & - \\
\hline Other humans & $24 \%$ & $5 \%$ \\
\hline Intra-text & - & $4 \%$ \\
\hline Inter-text & $29 \%$ & $1 \%$ \\
\hline Existential & $9 \%$ & $1 \%$ \\
\hline Mental/Argument & $17 \%$ & $1 \%$ \\
\hline Time & $1 \%$ & $7 \%$ \\
\hline
\end{tabular}

In the case of the Journal des Sçavans, the most frequent types of theme are Inter-text, accounting for $29 \%$, and Other humans, accounting for $24 \%$. The category Inter-text comprises themes which relate to texts other than the entry in the Journal des Sçavans itself, and Other humans refers to humans other than the writer of the Journal des Sçavans entry. These are usually the book under review, and the author of that book. Hence, it can be seen that this derives directly from the fact that an editorial choice has been made to devote the periodical mainly to book reviews.

In the case of the Philosophical Transactions, the category of Object of study accounts for over three-quarters (77\%) of the topical themes. The Object of study is the item or phenomenon which is being experimented on, observed, or described. This is obviously physical in nature and reflects the editorial decision to restrict the Philosophical Transactions to the field of "natural philosophy".

Thus, in the following example from the Journal des Sçavans, the topical theme, La Compilation des Conciles d'Angleterre entreprise par Spelman, is of the "inter-text" type, and refers to the book under review:

La Compilation des Conciles d'Angleterre enterprise par Spelman, est diuisée en deux parties. (Journal des Sçavans, 9 mars 1665) ${ }^{4}$

In the following example from the Philosophical Transactions, the topical theme, the Sea, here preceded by two textual themes And and thus, falls into the "object of study" category:

And thus the Sea ebbs and flows orderly, some 4. days before the full Moon, and change, and as long after (the ordinary Spring-tides rising some 14; or 15. foot upright, and all the rest proportionably, as in other places. (Philosophical Transactions, 5 June 1665)

The type of thematic progression present in the two journals is shown in Table 2. In the case of the Journal des Sçavans, $82 \%$ of the clauses could be clearly analysed as linear (derived from a preceding rheme) or constant (derived from a preceding theme). In the case of the Philosophical Transactions the figure was 78\%. The remainder of the themes were either new, or could not be clearly analysed as linear or constant. 
Table 2. Thematic progression as percentage of clauses

\begin{tabular}{|l|c||c|}
\hline & $\begin{array}{c}\text { Journal des } \\
\text { Sçavans }\end{array}$ & $\begin{array}{c}\text { Philosophical } \\
\text { Transactions }\end{array}$ \\
\hline Linear & $48 \%$ & $55 \%$ \\
\hline Constant & $34 \%$ & $23 \%$ \\
\hline
\end{tabular}

26 Although linear progression is the commonest form in both, it can be seen that this is rather more so in the case of the Philosophical Transactions. Since linear progression is usually associated with argumentative texts, and constant progression with descriptive texts, this might suggest that the items in the Philosophical Transactions tend more towards the argumentative than those in the Journal des Sçavans. It could be argued that this is due to the more experimental bent of the former journal, while the Journal des Sçavans describes the content of the books under review.

Thus in the following extract from the Journal des Sçavans, there are three ranking clauses, whose topical themes are, Ce vocabulaire, cette derniere edition and Il. These are obviously derived from each other, and thus constitute a short sequence of constant progression:

Ce vocabulaire a desia esté Imprimé plusieurs fois: mais cette derniere edition est beaucoup plus ample que toutes les autres. Il contient vn tresgrand nombre de mots propres à toute sorte d'arts \& de sciences, qu'on auroit de la peine à trouuer ailleurs. (Journal des Sçavans, 9 mars 1665)

In the following extract from the Philosophical Transactions, the second topical theme This Hole being made as deep as is required is derived from the rheme of the previous clause, where the Hole is mentioned. This thus constitutes an example of linear progression:

And thus the work must be continued, till the Hole be 18. or 20. Inches deep, the deeper the better. This Hole being made as deep as is required, and kept as straight and smooth in the sides, as is possible, there is then a kind of double Wedge to be made, and fitted exactly for it, the shape whereof is to be seen in the annexed 3. Figure. (Philosophical Transactions, 3 July 1665)

\section{Linguistic features: process types}

Table 3 shows the distribution of process types present in the two journals. I use a system (Banks 2005) which has five process types: material (physical actions, events and happenings), mental (cerebral events of a cognitive, perceptive, or affective type), relational (relationships of an attributive, identifying or possessive nature), verbal (written or spoken communication), and existential (statements of existence). 
Table 3. Process Types

\begin{tabular}{|l|c|c|}
\hline & $\begin{array}{c}\text { Journal des } \\
\text { Sçavans }\end{array}$ & $\begin{array}{c}\text { Philosophical } \\
\text { Transactions }\end{array}$ \\
\hline Material & $18 \%$ & $44 \%$ \\
\hline Mental & $19 \%$ & $6 \%$ \\
\hline Relational & $30 \%$ & $39 \%$ \\
\hline Verbal & $27 \%$ & $6 \%$ \\
\hline Existential & $6 \%$ & $5 \%$ \\
\hline
\end{tabular}

The common feature is that of relational process, $30 \%$ in the case of the Journal des Sçavans and 39\% in the Philosophical Transactions. This indicates that description plays an important part in both journals. However the second commonest process type in the Journal des Sçavans is verbal process (27\%), showing that communication is the second most important feature here. This relates to the fact that the journal is basically book reviews, and books are a form of communication, as is discussion about them. This is consistent with the editorial decision to base the journal on book reviews, and also with the fact that the dominant themes deal with other texts (the books under review) and other humans (the authors of those books).

The distinguishing feature in the Philosophical Transactions is that material processes are even more common than relational processes, making material process the dominant type in this journal. This is consistent with the editorial decision to restrict content to the sciences and technology, thus giving it a strongly physical orientation, reflected in the use of material process. It is also consistent with the fact that three-quarters of the themes are of a physical nature relating to the object under observation or subject to experiment. It will be noted that in comparison, in the Journal des Sçavans only $18 \%$ of the processes are material; and on the other hand, in the Philosophical Transactions only $6 \%$ of the processes are verbal.

Thus in the following example from the Journal des Sçavans, the verbs enseigne and descrit encode verbal processes:

Dans la premiere, Monsieur de Willis enseigne vne nouuelle maniere de dissequer le Cerueau, \& en suitte descrit toutes les parties qui le composent ; s'estendant principalement sur celles qu'il a nouuellement descouuertes. (Journal des Sçavans, 12 janvier 1665)

In the following example from the Philosophical Transactions, the verbs break and put encode material processes:

To make Brimstone, they break the Stone or Ore into small pieces, which they put into Crucibles made of Earth, five foot long, square and Pyramid-wise. (Philosophical Transactions, 8 May 1665) 


\section{Linguistic features: modality}

Table 4 shows the distribution of types of modality in the two journals.

Table 4. Types of modality

\begin{tabular}{|l|c|c|}
\hline & Journal des Sçavans & Philosophical Transactions \\
\hline Epistemic & $26 \%$ & $19 \%$ \\
\hline Dynamic & $51 \%$ & $77 \%$ \\
\hline Deontic & $22 \%$ & $4 \%$ \\
\hline
\end{tabular}

Dynamic modality, which deals with questions of a physical nature, such as physical possibility, physical ability, and so on, is the dominant type of modality in both journals. However this is much more so in the case of the Philosophical Transactions, where it accounts for $77 \%$ of the modal expressions, as opposed to $51 \%$ in the Journal des Sçavans. Epistemic modality, which deals with human judgement of likelihood, on a scale from possibility to certainty, is of the same order in both journals, though slightly more common in the Journal des Sçavans. On the other hand deontic modality, dealing with questions of a moral order, notably obligation and permission, accounts for $22 \%$ of the modal expressions in the Journal des Sçavans, but is only marginally present in the Philosophical Transactions, accounting for only $4 \%$. This again shows the bias of the Philosophical Transactions towards questions of a physical nature derived from Oldenburg's editorial decision to restrict the journal to material of a physical nature, while the presence of a significant number of occurrences of deontic modality in the Journal des Sçavans reflects the inclusion of subjects such as theology and law in its allembracing subject range.

The two occurrences of the verb devoir in the following extract from the Journal des Sçavans are examples of deontic modality:

Mais c'est dequoy on se plaint, que M. Patin ait nommé Sauot, où il ne deuoit pas le faire ; \& qu'il ait supprimé son nom, lors qu'il le deuoit nommer ; c'està-dire, quand il a parlé de ceux qui ont bien escrit des Medailles. (Journal des Sçavans, 9 mars 1665)

In the following extract from the Philosophical Transactions, there are six examples of dynamic modality, represented by the verbs may, and must (two occurrences each), and the expressions is necessary and is to be:

Now that there may be no want of such fresh Air, the Fire must always be kept burning in the Chimney, or, at least as frequently as is necessary: For which purpose there must be two of the Iron Grates or Chimneys, that when any accident befalls the one, the other may be ready to be put in its place, the Coals being first well kindled in it: but when the fire is neer spent, the Chimney or Grate being haled up to the dore, is to be supplied with fresh fuel. (Philosophical Transactions, 3 July 1665) 


\section{Concluding remarks}

We have seen that there is a stark contrast between the historical context of the late seventeenth century in France, compared to that of England. We have also seen that Denis de Sallo, as editor of the Journal des Sçavans, and Henry Oldenburg, as editor of the Philosophical Transactions, made very different editorial decisions, but decisions that derived from and were part of their respective cultural contexts. The texts published as a result of those editorial decisions display differing linguistic features. The fact that the Journal des Sçavans is made up of book reviews leads to the use of those texts and their authors as themes of the clauses; it also leads to the frequent use of verbal processes, since what is being talked about is communication through the books concerned. The fact that this journal treats the full range of human knowledge leads to increased use of constant thematic process due to the fact that the books are being described. The inclusion of areas such as theology leads to the use of deontic modality. The fact that the Philosophical Transactions is based on Oldenburg's correspondence leads to the use of linear thematic progression, as the letters give argued accounts of the observations and experiments reported. The fact that it deals only with science and technology leads to numerous themes connected to the object of study, and the use of material process. These two journals are clear examples of the way in which texts are the product of their contexts, and can only be fully comprehended in terms of the contexts which produce them. This is of particular interest to ESP because it is the beginnings from which the academic research article began. I wish to claim that this type of interest can be found in all types of diachronic ESP.

Several years ago, Michel Petit's seminal article on FASP (fiction à substrat professionnel) (Petit 1999) provided a meeting place, or interface, between linguistics and literature in an ESP context. Petit's point is that works of popular fiction set in a professional or specialized context frequently include passages with the same linguistic features as genuine texts from that domain. As such they can provide a legitimate, and for students, motivating, entry point to the study of specialized text. This created an academic space where linguists could meet literature specialists, or those working in ESP, but with an interest in literature, could find a home. I would like to think that diachronic ESP could do the same sort of thing for linguistics and cultural studies, so that those with an interest in both, or linguists working with specialists in civilisation, could find a working space in an ESP environment.

I would like to thank Michel Van der Yeught and two anonymous referees for their helpful comments. It goes without saying that they are in no way responsible for any shortcomings which remain.

\section{BIBLIOGRAPHY}

Auffray, Jean-Paul. 2000. Newton ou le triomphe de l'alchimie. Paris: Le Pommier. 
Banks, David. 2004. "Philosophy, science, ideology and the establishment of science as a profession". ASp 43-44, 69-80.

Banks, David. 2005. Introduction à la linguistique systémique fonctionnelle. Paris: L'Harmattan. Banks, David. 2008. The Development of Scientific Writing, Linguistic Features and Historical Context. London: Equinox.

Banks, David. 2009. "Creating a specialized discourse: the case of the Philosophical Transactions". ASp 56, 29-44.

Banks, David. 2010a. "The beginnings of vernacular scientific discourse: genres and linguistic features in some early issues of the Journal des Sçavans and the Philosophical Transactions". E-rea, 8/1 <http://erea.reviews.org/1334>.

Banks, David. 2010b. "Transitivity and thematic structure in some early issues of the Philosophical Transactions". ASp 58, 57-71.

Banks, David. Forthcoming. "Les formes et fonctions de la modalité dans le Journal des Sçavans et les Philosophical Transactions à la fin du $17^{\text {ème }}$ siècle”. In Banks, David (ed.), La modalité dans le texte de spécialité. Paris: L'Harmattan.

Biaglioni, Mario. 1996. "Etiquette, interdependence, and sociability in seventeenth century science". Critical Inquiry 22/2, 193-238.

Birn, Raymond. 1965. "Le Journal des Savants sous l'ancien régime”. Journal des Savants janviermars, 15-35.

Bluhm, R.K. 1960. “Henry Oldenburg, F.R.S. (c. 1615-1677)”. In Hartley, Harold (ed.), The Royal Society. Its origins and founders. London: The Royal Society.

Camusat, Denis François. 2011 [1734]. Histoire critique des journaux. Charleston: Nabu Press [facsimile of 1734 edition. Amsterdam: J.F. Bernard].

Cocheris, Hippolyte. 1860. Histoire du Journal des Savants depuis sa fondation jusqu'à nos jours. Paris: A. Durand.

Darembeerg, Charles. 1859. “Journal des Savans (1665-1859)”. Journal des Débats Politiques et Littéraires 20 avril 1859, 2-3.

Fara, Patricia. 2002. Newton, The making of Genius. London: Picador.

Gleik, James. 2003. Isaac Newton. London: 4th Estate.

Golinski, Jan. 1989 [1988]. “The secret life of an alchemist”. In Fauvel, John, Raymond Flood, Michael Shortland \& Robin Wilson (eds.), Let Newton Be! A new perspective on his life and works. Oxford: Oxford University Press, 147-167.

Gotti, Maurizio. 2006. "Disseminating early modern science: specialized news discourse in the Philosophical Transactions”. In Brownlees, Nicholas (ed.), News Discourse in Early Modern Britain. Bern: Peter Lang, 41-70.

Gribbin, John. 2005. The Fellowship, The Story of a Revolution. London: Allen Lane.

Hahn, Roger. 1971. The Anatomy of a Scientific Revolution, The Paris Academy of Sciences, 1666-1803. Berkeley: University of California Press.

Halliday, M.A.K. (revised by Christian M.I.M. Matthiessen). 2004. An Introduction to Functional Grammar, 3rd edn. London: Arnold.

Hall, Marie Boas. 2002. Henry Oldenburg, Shaping the Royal Society. Oxford: Oxford University Press. 
Henry, John. 2002. Knowledge is Power, Francis Bacon and the Method of Science. Cambridge: Icon Books.

Hill, Christopher. 1969 [1961]. The Century of Revolution 1603-1714. London: Sphere Books.

Hirschfield, John Milton. 1981. The Académie Royale des Sciences 1666-1683. New York: Arno Press. Hunter, Michael. 2010 [2009]. Boyle, Between God and science. New Haven: Yale University Press. Jones, Richard Foster. 1982 [1961]. Ancients and Moderns, A study of the rise of the scientific movement in seventeenth century England, 2nd edn. New York: Dover Publications.

Licoppe, Christian. 1994. "The crystallization of a new narrative form in experimental reports (1660-1690). The experimental evidence as a transaction between philosophical knowledge and aristocratic power". Science in Context 7/2, 205-244.

Licoppe, Christian. 1996. La formation de la pratique scientifique. Le discours de l'expérience en France et en Angleterre (1630-1820). Paris: La Découverte.

Lyons, Henry. 1944. The Royal Society 1660-1940, A history of its administration under its charters. Cambridge: Cambridge University Press.

Merton, Robert K. 1938. "Science, technology and society in seventeenth century England". Osiris $4,360-632$.

Morgan, Betty Trebelle. 1928. Histoire du Journal des Sçavans depuis 1665 jusqu'en 1701. Paris: Presses Universitaires de France.

Newton, Isaac. 1952 [1730]. Opticks, or a treatise of the reflections, refractions, inflections \& colours of light, 4 th edn. New York: Dover.

Panza, Marco. 2003. Newton. Paris: Les Belles Lettres.

Paris, Gaston. 1903. “Le Journal des Savants”. Journal des Savants janvier 1903, 5-34.

Peiffer, Jeanne \& Jean-Pierre Vittu. 2008. "Les journaux savants, formes de la communication et agents de la construction des savoirs (17 ${ }^{\mathrm{e}}-18^{\mathrm{e}}$ siècles)”. Dix-huitième siècle 40, 281-300.

Petit, Michel. 1999. "La fiction à substrat professionnel : une autre voie d'accès à l'anglais de spécialité". ASp 23-26, 57-84.

Robertson, John M. (ed.). 1905. The Philosophical Works of Francis Bacon. London: George Routledge and Sons.

Sorrenson, Richard. 1996. "Towards a history of the Royal Society in the eighteenth century". Notes and Record of the Royal Society of London 50/1, 29-46.

Sprat, Thomas. 2003 [1667]. History of the Royal Society of London for the Improving of Natural Knowledge. Whitefish, MT: Kissinger [facsimile of 1667 edition, London, J. Martyn].

Vittu, Jean-Pierre. 2001. “Qu'est-ce qu'un article au Journal des savants de 1665-1714 ?". Revue française d'histoire du livre 112/113, 129-148.

Vittu, Jean-Pierre. 2002a. "La formation d'une institution scientifique : le Journal des Savants de 1665 à 1714. Premier article : D'une entreprise privée à une semi-institution”. Journal des Savants janvier-juin 2002, 179-203.

Vittu, Jean-Pierre. 2002b. "La formation d'une institution scientifique : le Journal des Savants de 1665 à 1714. Second article : L'instrument central de la République des Lettres”. Journal des Savants juillet-décembre 2002, 347-377. 
Vittu, Jean-Pierre. 2005. "Du Journal des savants aux Mémoires pour l'histoire des sciences et des beauxarts : l'esquisse d'un système européen des périodiques savants”. Dix-septième siècle 228, 527-545.

Weber, Max (trans. Talcott Parsons). 1930. The Protestant Ethic and the Spirit of Capitalism. London: George, Allen \& Unwin.

White, Michael. 1998 [1997]. Isaac Newton, The last sorcerer. London: $4^{\text {th }}$ Estate.

\section{NOTES}

1. An earlier version of this paper was given at the Congrès de la SAES, Paris 20-22 May 2011.

2. This does not mean that there were no difficulties at all; for example, the opposition of the Fronde. was a disturbance to be overcome in the early years of his reign.

3. There have been a number of accounts of the history of the Journal des Sçavans, or discussion of aspects of that history, from the early eighteenth century to the present day. Readers interested in this may find some of the following of interest: Birn 1965; Camusat 2011; Cocheris 1860; Daremberg 1859; Morgan 1928; Paris 1903; Vittu 2001, 2002a, 2002b, 2005; Peiffer \& Vittu 2008.

4. In examples, the original spelling and typography have been preserved as far as possible, the notable exception being "long s".

\section{ABSTRACTS}

Diachronic studies are of interest for ESP. For example, The Journal des Sçavans and the Philosophical Transactions both started in 1665, the former in a highly stable and centralized France, and the latter in an England which had gone through a seriously troubled period, but which was now optimistic in the light of the Restoration of the monarchy. The editors of these two journals, Denis de Sallo and Henry Oldenburg, made decisions which were a function of their respective historical contexts. The linguistic features found in early issues reflect these editorial decisions showing that the texts must be understood in terms of their context. Diachronic ESP can thus be a meeting place for linguistics and cultural studies in an ESP perspective.

Les études diachroniques sont d'un grand intérêt pour l'anglais de spécialité. À titre d'exemple, le Journal des Sçavans et les Philosophical Transactions ont, tous les deux, vu le jour en 1665, le premier dans une France très stable et centralisée, le deuxième dans une Angleterre, qui, ayant traversé une période très troublée, baignait dans l'optimisme de la Restauration de la monarchie. Les rédacteurs de ces deux périodiques, Denis de Sallo et Henry Oldenburg, prirent des décisions qui tenaient à leurs situations historiques respectives. Les traits linguistiques qui se trouvent dans les premiers numéros reflètent ces décisions éditoriales, démontrant ainsi qu'il faut comprendre ces textes en fonction de leur contexte. L'anglais de spécialité diachronique peut, de ce fait, fournir un terrain où linguistique et civilisation peuvent se rencontrer dans cette optique précise. 
INDEX

Keywords: academic periodical, diachronic ESP, modality, process, 17th century, theme

Mots-clés: anglais de spécialité diachronique, XVIIe siècle, modalité, périodique savant, procès, thème

\section{AUTHOR}

\section{DAVID BANKS}

David Banks is Emeritus Professor of English Linguistics at the Université de Bretagne Occidentale, Brest. He is director of ERLA (Équipe de recherche en linguistique appliquée) and chairman of AFLSF (Association française de la linguistique systémique fonctionnelle). His recent publication The Development of Scientific Writing won the ESSE Language and Linguistics Book Award 2010. David.Banks@univ-brest.fr 